\title{
The repair of complex penile defect with composite anterolateral thigh and vascularized fascia lata flap
}

\author{
Şükrü Yazar, M.D., ${ }^{1}$ Muzaffer Eroğlu, M.D., ${ }^{2}$ Ali Gökkaya, M.D., ${ }^{3}$ Atilla Semerciöz, M.D. ${ }^{2}$ \\ ${ }^{1}$ Department of Plastic and Reconstructive Surgery, Acıbadem University Faculty of Medicine, İstanbul \\ ${ }^{2}$ Department of Urology, Abant İzzet Baysal University Faculty of Medicine, Bolu \\ ${ }^{3}$ Department of Plastic and Reconstructive Surgery, Abant İzzet Baysal University Faculty of Medicine, Bolu
}

\begin{abstract}
One-stage reconstruction of complex penile defects with functional and cosmetic results is a challenging procedure. The selection of proper technique and materials for reconstruction depends on the type of the deficient tissue components, the size of the wound surface, and the donor site. This article presented a case of a partial penile and urethral defect due to an infection in the previous surgical site. The patient was treated with a perforator based pedicled composite anterolateral thigh flap combined with vascularized fascia lata.The urethral defect was reconstructed with the vascularized fascia lata. The remaining part of the flap was used for the resurfacing of the right cavernous body and penile skin defect. There was no fistula and the urinary caliber was accepted as good. The pedicled composite anterolateral thigh flap contains various tissue components suitable for a functional and cosmetic reconstruction of complex penile defects using the one-stage technique.
\end{abstract}

Key words: Complex penile defect; perforator based pedicled anterolateral thigh flap; vascularized fascia lata.

\section{INTRODUCTION}

Complex penile defects involving the urethra, cavernous bodies, and penile or scrotal skin may result from congenital hypospadias, trauma, burn, infection, and cancer surgery. Although several different repair techniques have been described, reconstruction of complex penile defects is quite challenging. As well as the ability to urinate, a reconstructed penis and urethra should ensure erectile function, tactile sensibility, sexual satisfaction, and aesthetic integrity.

Many methods of restoring urethral continuity and/or resurfacing of penile skin defects have been described. Various graft materials such as genital or extra genital skin or mucosa

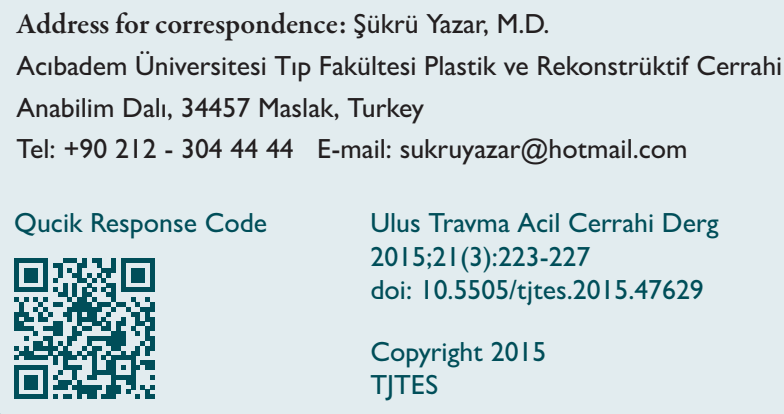

have been used for establishing a normal urethral lumen, ${ }^{[1-5]}$ or split-thickness skin grafts used for coverage of a denuded penile shaft. ${ }^{[6]}$ Local pedicled penile or scrotal flaps and pedicled regional flaps have allowed reliable long-term results to create a solution to long urethral defects and resurfacing of large penile skin defects. ${ }^{[7-13]}$ Unfortunately, previous surgery or trauma may preclude using local pedicled penile and regional flaps. Recently, microsurgical transfers of different tissues have been used for reconstruction of the more complex urethral and penile defects. ${ }^{[12,14-17]}$

This study aimed to report a case of a partial penile and urethral defect due to an infection in the previous surgical site of a penile fracture. The complex penile defect was reconstructed with a perforator based pedicled anterolateral thigh flap combined with the vascularized fascia lata. The urethral defect was reconstructed with the vascularized fascia lata. The remaining part of the flap was used for the resurfacing of the right cavernous body and penile skin defects.

\section{CASE REPORT}

A 42-year-old male patient was admitted to our hospital with pain and dark-brown discoloration of his penis. The patient was healthy and did not have any diseases like DM. The patient had been operated on for a penile fracture ten days pri- 
or in another hospital and discharged from the hospital eight days after surgery. Local examination revealed infection and necrosis of the penile skin without any clear line of demarcation (Fig. Ia). The patient was hospitalized and a sistofix was inserted into his bladder. The wound was managed with repeated debridements of necrotic tissues, culture specific antibiotics, and meticulous local wound care for the eradication of the infection. Unfortunately, after serial debridements of necrotic tissues a right cavernous body, a $5-6 \mathrm{~cm}$ urethral, and a partial penile skin defect occurred (Figs. Ib, c).

\section{Surgical Technique}

A $7 \times 16 \mathrm{~cm}$ dimensional anterolateral thigh flap was designed on the right side. The location of the main cutaneous perforators was detected and marked with an ultrasound Doppler preoperatively. A medial incision above the rectus femoris muscle was made and deepened down to the subfascial plane. The pedicle was identified in the intermuscular septum between the rectus femoris and vastus lateralis muscle. The dissection continued underneath the deep fascia of the vastus lateralis muscle to determine the relation of the perforators between the muscle and deep fascia. ${ }^{[18,19]}$ Two musculocutaneous perforators were observed. Intramuscular dissection of the perforators through the muscle down to their origin on the main pedicle was performed under surgical loupe magnification. The muscle around the perforator was divided piece-by-piece following their course, and all tiny muscular branches were carefully ligated with hemoclips or cauterized with bipolar cautery. Later, the main pedicle, descending branch of the lateral circumflex femoral artery, was dissected and isolated to preserve the motor nerve to the vastus lateralis muscle and rectus femoris muscle. The entire length of the perforator flap pedicle was $16 \mathrm{~cm}$.

At the upper portion of the flap, the lateral cutaneous femoral nerve was identified in subcutaneous tissue and dissected at the suprafascial level toward the anterior superior iliac spine for sensation of the skin island (Fig. Id).

The dissection was extended laterally to the vastus lateralis muscle to include the adjoining fascia lata. Together with an adequate fascia lata strip, the flap was elevated as a composite flap. A tunnel was created under the adjacent muscles and skin in order to reach the defect on the penis.

Under magnification, a part of the fascia lata was dissected and separated from the skin island in a thin layer at the dis-
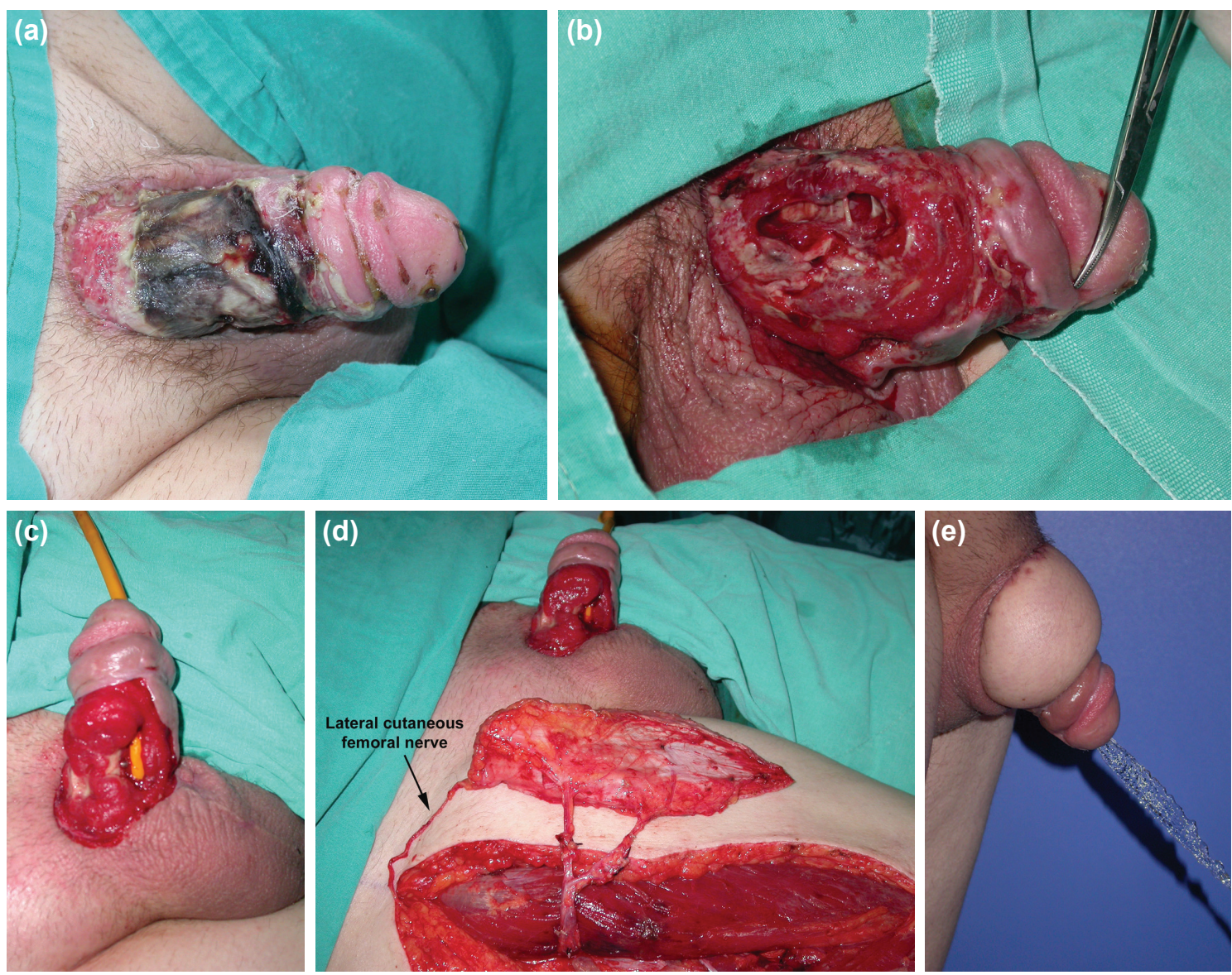

Figure 1. (a) Necrotic tissue of the penis after first debridement. (b) Right cavernous body defect. (c) Urethral and skin defects. (d) The sensate perforator based pedicled composite anterolateral thigh flap combined with vascularized fascia lata. (e) Urination with good caliber 14 months after operation. 
tal part of the flap. The lateral and ventral semicircular wall defect of the urethra was reconstructed with the dissected vascularized fascia lata and the overlying skin was used to cover the reconstructed urethra. The remaining skin and vascularized fascia lata of the composite flap was used for the resurfacing of the right cavernous body and penile skin defect. The donor site of the flap was closed primarily. No complications were observed during the postoperative period.

The urinary diversion was clamped and the urethral catheter was taken out three weeks post reconstruction. Even from the early post-operative period, the patient urinated easily. External urethral meatus stenosis occurred two times in the first month and it was dilated with the passage of metal rods. No urination problems were observed during the 24-month long postoperative follow up. There was no fistula and the urinary caliber was accepted as good (Fig. Ie). Normal protective sensation and tactile sensibility were recorded with two-point discrimination test. The patient reported penile erectile function and ability to perform intercourse despite a right side penile curvature, 10 months after the operation. He had a baby 2 years after surgery.

\section{DISCUSSION}

One-stage reconstruction of the urethra, cavernous bodies, and penile or scrotal skin defects with functional and cosmetic results presents reconstructive challenges to the surgeon. The selection of proper techniques and tissue for reconstruction of such complex penile defects usually depends on the type of the deficient tissue components, the size of the defects, the status of the wound, the condition of local tissues, and the donor site and its morbidity.

Genital or extra genital skin or mucosal grafts require close contact with a well-vascularized recipient bed. Any loss of the graft could result in recurrent stricture and increase scar tissues. ${ }^{[4,7,8,16,17]}$ The advantage of using a flap for urethral reconstruction is that viability does not depend on the quality of the recipient bed. ${ }^{[7-9,12,16,17]}$ In addition, the superiority of skin flaps to skin graft is obvious for the resurfacing of a large or a denuded penile shaft. ${ }^{[10-13]}$ Therefore, many local and regional flap options have been reported. ${ }^{[7-13]}$ However, these flaps usually require a two-stage procedure, they have limited dimensions, and previous surgery or trauma may preclude using these local penile or regional flaps. When grafts and pedicle flaps are inadequate or unavailable, microsurgical transfers of fasciocutaneous flaps, the appendix, and intestinal segments are possible tissues for the reconstruction of more complex urethral and penile defects. ${ }^{[12,14-17]}$

Although the safety and versatility of microvascular free tissue transfer for reconstruction of complex penile defects is impressive, it is time consuming and it necessitates microsurgical experience. The free radial forearm flap has been widely used for both penis reconstruction and penile resurfacing. Its disadvantages are donor-site morbidity, limited dimensions, the complexity of the free tissue transfer procedure, significant atrophy of the flap, and relatively poor reinnervation. $[12,13,15]$ Intestinal and appendix free flaps should be considered in situations when the other urethral reconstruction methods cannot be safely used. Patients must undergo a laparotomy to harvest these flaps. This surgery requires a full day and patients must be able to safely withstand lengthy anesthesia. Furthermore, sacculation of the neourethra may develop when intestine is used, which could lead to post-voit dribbling, infection and even stone formation. ${ }^{[16,17]}$

However, none of these techniques, excluding tubed skin grafts and flaps, are popular for urethral reconstruction. Urethral reconstruction using tube-shaped skin grafts or flaps are not always successful because of postoperative complications such as infection, hair growth, fistula, stone formation, diverticula, and strictures. ${ }^{[4,12,15-17]}$
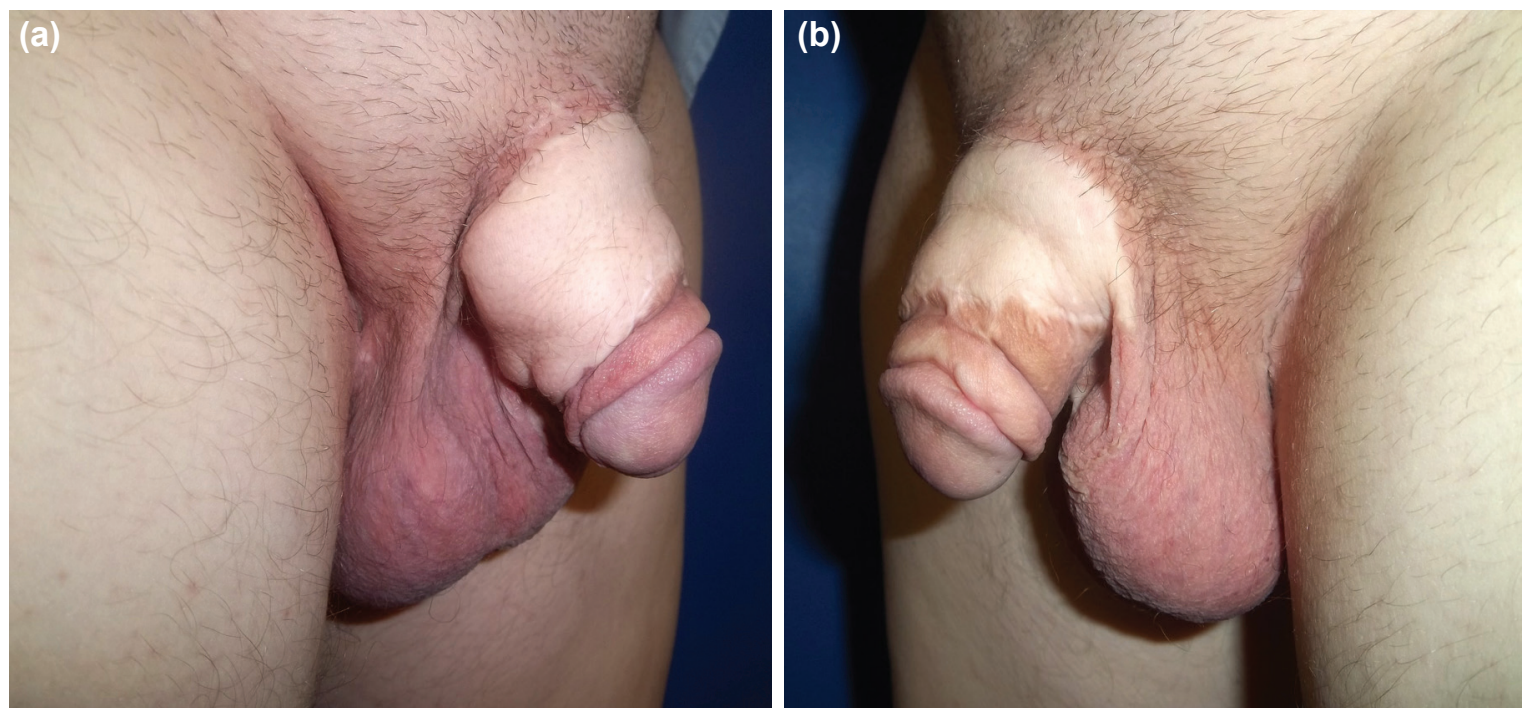

Figure 2. (a, b) The reconstructed penis. 
In this patient, the urethral defect was reconstructed with the vascularized fascia lata and the right cavernous body and penile skin defects were resurfaced with the remaining part of the flap in one-stage. In previous reports, the fascia lata had been used for urethral reconstruction as a non-vascularized graft. ${ }^{[5,18]}$ In this patient, the fascia lata was transferred and combined to the anterolateral thigh flap as a vascularized graft. The fascia lata received sufficient blood supply via the prefascial and subfacial vascular plexus when attached to the anterolateral thigh flap. ${ }^{[19,20]}$ The fascia lata has a pliable and stretchable structure. These characteristics may help create a tube-shaped neo-urethra. Furthermore, the fascia lata has no hair; therefore, postoperative complications such as, infection, stone formation, fistula and strictures may occur less. The other advantage of using a vascularized fascia lata graft for urethral reconstruction is that the viability does not depend on the quality of the recipient bed.

Penile erectile function and the subsequent ability to perform intercourse can be preserved by the use of gliding tissue for penile coverage. The anterolateral thigh flap combined with vascularized fascia lata has been successfully used for the resurfacing of penile skin defects. ${ }^{[13]}$ The vascularized fascia lata is a suitable tissue for providing an appropriate gliding effect to the overlying skin for penis resurfacing. ${ }^{[13]}$ On the other hand, an anterolateral thigh flap combined with a vascularized fascia lata may be too bulky for resurfacing a penis, but it can be safely thinned in a second stage procedure. In this patient the bulky appearance of the flap was thinned by a defatting and liposuction technique in the plane between the fascia lata and skin (Figs. 2a, b).

Therefore, composite anterolateral thigh flap combined with a vascularized fascia lata may tolerate the subsequent secondary surgical procedures because of the rich subcutaneous vascular plexus, which permits a reliable surgical dissection. Furthermore, this flap may provide skin component continuity with the surrounding skin, which may present better venous and lymphatic drainage and a better cosmetic appearance. ${ }^{[21]}$

The advantages of the anterolateral thigh flap were reported previously. The flap has a large cutaneous area. ${ }^{[22]}$ In chimeric flap principle, the flap can be combined with adjacent tissues such as the rectus femoris muscle, the tensor fasciae latae muscle, and the fascia lata. ${ }^{[22,23]}$ The long vascular pedicle provides a long rotation arch when transferred as a pedicled flap. It is a potentially sensate flap when the lateral cutaneous nerve is included in the flap. The donor site morbidity is minimal, and the scar is easily concealed. ${ }^{[22,23]}$

The perforator based pedicled anterolateral thigh flap combined with vascularized fascia lata can easily reach and cover the entire surface of the penis. The main advantage of this composite flap is that it may provide a large amount of sensate skin for a penile shaft and a large amount of well-vascularized and hairless fascia lata for urethral conduit recon- struction, without the need for microsurgery. This technique can be used for one-stage reconstruction of complex penile defect or total penile reconstruction.

Harvesting of the pedicled anterolateral thigh flap combined with vascularized fascia lata is safe and fast. The flap can contain various tissue components for functional and cosmetic reconstruction of complex penile defects in one-stage without the need for microsurgical procedures. Therefore, this flap may be a good alternative for urethral conduit and penile shaft reconstruction.

\section{Conflict of interest: None declared.}

\section{REFERENCES}

1. Latifoğlu O, Yavuzer R, Unal S, Cavuşoğlu T, Atabay K. Surgical treatment of urethral fistulas following hypospadias repair. Ann Plast Surg 2000;44:381-6. CrossRef

2. El-Sherbiny MT, Abol-Enein H, Dawaba MS, Ghoneim MA. Treatment of urethral defects: skin, buccal or bladder mucosa, tube or patch? An experimental study in dogs. J Urol 2002;167:2225-8. CrossRef

3. Ransley PG, Duffy PG, Oesch IL, Van Oyen P, Hoover D. The use of bladder mucosa and combined bladder mucosa/preputial skin grafts for urethral reconstruction. J Urol 1987;138(4 Pt 2):1096-8.

4. Kahveci R, Kahveci Z, Sirmali S, Ozcan M. Urethral reconstruction with autologous vein graft: an experimental study. Br J Plast Surg 1995;48:500-3. CrossRef

5. Kargi E, Yeşilli C, Akduman B, Babucçu O, Hoşnuter M, Mungan A. Fascia lata grafts for closure of secondary urethral fistulas. Urology 2003;62:928-31. CrossRef

6. Georgiou P, Liakopoulos P, Gamatsi E, Komninakis E. Degloving injury of the penis from pig bite. Plast Reconstr Surg 2001;108:805-6. CrossRef

7. Wessells H, McAninch JW. Current controversies in anterior urethral stricture repair: free-graft versus pedicled skin-flap reconstruction. World J Urol 1998;16:175-80. CrossRef

8. Jordan GH. Penile reconstruction, phallic construction, and urethral reconstruction. Urol Clin North Am 1999;26:1-13. CrossRef

9. Secrest CL, Jordan GH, Winslow BH, Horton CE, McCraw JB, Gilbert DA, et al. Repair of the complications of hypospadias surgery. J Urol 1993;150(5 Pt 1):1415-8.

10. Jeong JH, Shin HJ, Woo SH, Seul JH. A new repair technique for penile paraffinoma: bilateral scrotal flaps. Ann Plast Surg 1996;37:386-93. CrossRef

11. Borovikov A, Scheplev P. Axial flaps for treatment of penis lesions due to granulomas. Ann Plast Surg 1990;25:116-8. CrossRef

12. Cheng KX, Hwang WY, Eid AE, Wang SL, Chang TS, Fu KD. Analysis of 136 cases of reconstructed penis using various methods. Plast Reconstr Surg 1995;95:1070-84. CrossRef

13. Gravvanis AI, Tsoutsos DA, Iconomou TG, Papadopoulos SG. Penile resurfacing with vascularized fascia lata. Microsurgery 2005;25:462-8.

14. Young VL, Khouri RK, Lee GW, Nemecek JA. Advances in total phalloplasty and urethroplasty with microvascular free flaps. Clin Plast Surg 1992;19:927-38.

15. Gottlieb LJ, Levine LA. A new design for the radial forearm free-flap phallic construction. Plast Reconstr Surg 1993;92:276-84. CrossRef

16. Koshima I, Inagawa K, Okuyama N, Moriguchi T. Free vascularized appendix transfer for reconstruction of penile urethras with severe fibrosis. Plast Reconstr Surg 1999;103:964-9. CrossRef

17. Bales GT, Kuznetsov DD, Kim HL, Gottlieb LJ. Urethral substitution using an intestinal free flap: a novel approach. J Urol 2002;168:182-4.

18. Atalan G, Cihan M, Sozmen M, Ozaydin I. Repair of urethral defects 
using fascia lata autografts in dogs. Vet Surg 2005;34:514-8. CrossRef

19. Cormack GC, Lamberty BG. The blood supply of thigh skin. Plast Reconstr Surg 1985;75:342-54. CrossRef

20. Taylor GI, Palmer JH. The vascular territories (angiosomes) of the body: experimental study and clinical applications. Br J Plast Surg 1987;40:113-41.

21. Yazar S, Lin CH, Lin YT, Ulusal AE, Wei FC. Outcome comparison between free muscle and free fasciocutaneous flaps for reconstruction of distal third and ankle traumatic open tibial fractures. Plast Reconstr Surg
2006;117:2468-77. CrossRef

22. Wei FC, Jain V, Celik N, Chen HC, Chuang DC, Lin CH. Have we found an ideal soft-tissue flap? An experience with 672 anterolateral thigh flaps. Plast Reconstr Surg 2002;109:2219-30. CrossRef

23. Kuo YR, Kuo MH, Chou WC, Liu YT, Lutz BS, Jeng SF. One-stage reconstruction of soft tissue and Achilles tendon defects using a composite free anterolateral thigh flap with vascularized fascia lata: clinical experience and functional assessment. Ann Plast Surg 2003;50:149-55. CrossRef

\section{OLGU SUNUMU - ÖZET}

\section{Kompleks penis defektinin kompozit anterolateral uyluk ve vaskülarize fasta lata flebi ile onarımı \\ Dr. Şükrü Yazar, ${ }^{1}$ Dr. Muzaffer Eroğlu, ${ }^{2}$ Dr. Ali Gökkaya, ${ }^{3}$ Dr. Atilla Semerciöz ${ }^{2}$}

${ }^{1}$ Acıbadem Üniversitesi Tıp Fakültesi, Plastik ve Rekonstrüktif Cerrahi Anabilim Dalı, İstanbul

${ }^{2}$ Abant İzzet Baysal Üniversitesi Tıp Fakültesi, Üroloji Anabilim Dalı, Bolu

${ }^{3}$ Abant İzzet Baysal Üniversitesi Tıp Fakültesi, Plastik ve Rekonstrüktif Cerrahi Anabilim Dalı, Bolu

Kompleks penis defektlerinin estetik ve fonksiyonel sonuçlarla tek aşamalı onarımı oldukça zorlayıcı cerrahi prosedürlerdir. Rekonstrüksiyon için uygun teknik ve materyal seçimi, eksik dokuların tipi, yara yüzeyinin genişliği ve donör saha göz önünde bulundurularak yapılır. Bu yazıda, geçirilmiş cerrahi bölgesinde gelişen enfeksiyona bağlı olarak parsiyel penis ve üretral defekt oluşan bir olgu sunuldu. Hasta perforator bazlı pediküllü kompozit anterolateral uyluk flebi ve vaskülarize fasya lata ile tedavi edildi. Üretral defekt vaskülarize fasya lata ile rekonstrükte edildi. Flebin geri kalan kısmı sağ kavernöz cisim ve penisteki deri defektinin kapatılmasında kullanıldı. Rekonstrüksiyon sonrasında fistül gelişmedi ve üretra çapı iyi olarak nitelendirildi. Pediküllü kompozit anterolateral uyluk flebi, kompleks penis defektlerinin fonksiyonel ve estetik tek aşamalı rekonstrüksiyonuna uygun farklı doku komponentleri sunmaktadır.

Anahtar sözcükler: Kompleks penis defekti; perforator bazlı pediküllü anterolateral uyluk flebi; vaskülarize fasya lata.

Ulus Travma Acil Cerrahi Derg 2015;2I(3):223-227 doi: 10.5505/tjtes.2015.47629 